\title{
Acidic Polysaccharide Production from Methane by a New Methane-oxidizing Bacterium H-2
}

\author{
Kazuhiro CHIDA, Gwo-Jenn Shen, ${ }^{*}$ Tohru Kodama \\ and Yasuji MinODA \\ Department of Agricultural Chemistry, Faculty of Agriculture, \\ The University of Tokyo, Bunkyo-ku, Tokyo 113, Japan
}

Received June 22, 1982

\begin{abstract}
A thermophilic obligate methane-oxidizing bacterium, H-2, produced two kinds of extracellular acidic polysaccharides (Polymer I and Polymer II) from methane as a single carbon and energy source. The maximum total polysaccharide production was $1.8 \mathrm{~g}$, together with $3.6 \mathrm{~g}$ of dry cells, per liter of the culture medium. Polymer I and Polymer II contained $37 \%$ and $56 \%$ of sugars, respectively, consisting of glucose, mannose, galactosamine and glucuronic acid. In addition, these polysaccharides contained about $38 \%$ and $30 \%$ of amino acids, respectively.
\end{abstract}

Methane-oxidizing bacteria have a great advantage in production of single cell protein (SCP) because methane can be obtained in high purity and at relatively low cost. So many methane-oxidizing bacteria have been isolated and investigated. ${ }^{1 \sim 3)}$ We have isolated a new thermophilic obligate methane-oxidizing bacterium named $\mathrm{H}-2^{4)}$ for industrial SCP production. During the study of the culture conditions, we observed the production of extracellular polysaccharide by this strain. Some methylotrophs are known to produce extracellular substances such as polysaccharide from methanol, ${ }^{5)}$ and L-serine from glycine. ${ }^{6)}$ There are, however, only a few reports on the production of extracellular substances by microorganisms using methane as the carbon source. Söhngen reported that Pseudomonas methanica produced slime substances ${ }^{7)}$ and recently extracellular polysaccharide production was reported by a mixed methane-oxidizing culture during growth in methane. ${ }^{8)}$

In this paper, we dealt with the production of two kinds of polysaccharides by a pure culture of a new methane-oxidizing bacterium from methane as a single carbon and energy source, and with some properties of these polysaccharides.

\section{MATERIALS AND METHODS}

The microorganism and its culture. A thermophilic obligate methane-oxidizing bacterium, named $\mathrm{H}-2$ in the previous paper ${ }^{4}{ }^{4}$ was used throughout this study. The culture was carried out as follows: VCR medium ${ }^{4)}$ was used for the fundamental culture; the mixed gas consisted of $35 \%$ of methane, $10 \%$ of oxygen, $5 \%$ of carbon dioxide and $50 \%$ of air; the temperature was $50^{\circ} \mathrm{C}$.

A jar culture was carried out in a mini-type glass jar fermenter (total volume, 2-liters) containing 1 liter of the medium.

Measurements of growth and polysaccharide production. Growth was estimated by measuring optical density at $540 \mathrm{~nm}$ ( $1 \mathrm{OD}$ unit $=400 \mathrm{mg}$ dry cells per liter) with a spectrophotometer.

Polysaccharide was determined by Dubois' method ${ }^{9)}$ after the supernatant (crude polysaccharide solution) separated from culture broth by centrifugation at $10,000 \times g$ for $15 \mathrm{~min}$ had been dialyzed against deionized water for $6 \mathrm{hr}$ at $4^{\circ} \mathrm{C}$.

Purification of polysaccharide. Cetyltrimethylammonium bromide (CTAB) which forms an insoluble complex with anionic polymer was added to the crude polysaccharide solution until no more precipitate developed. The precipitate was washed with deionized water and dissolved in $1 \mathrm{M} \mathrm{NaCl}$. On adding four volumes of acetone to this solution, acidic polysaccharide was precipitated and CTAB remained in the supernatant. The polysaccharide was dissolved and dialyzed against deionized water for $24 \mathrm{hr}$ at $4^{\circ} \mathrm{C}$. Fractionation of the

* Author to whom reprint requests should be addressed. 
polysaccharide was carried out by stepwise precipitation with acetone. Purity of the polysaccharide was checked by sedimentation analysis using an analytical centrifuge (UCA-1, Hitachi Co. Ltd., Japan).

Investigation of some physicochemical properties of the polysaccharide. Molecular weight was estimated by sedimentation equilibrium analysis ${ }^{10}$ using the abovementioned analytical centrifuge at $25^{\circ} \mathrm{C}$. Viscosity was measured with an Ostwald's viscometer at $20.2^{\circ} \mathrm{C}$. Optical rotation was measured with an automatic polarimeter (DIP-4, JASCO, Japan) at $23.3^{\circ} \mathrm{C}$.

Investigation of components of the polysaccharide. Sugar components of the polysaccharide were analyzed by thin layer chromatography ${ }^{11)}$ and gas-liquid chromatography. ${ }^{12,13)}$ Especially, 2-aminohexosugar and glucuronic acid were estimated by Elson-Morgan's method ${ }^{14)}$ and Bitter-Muir's method, ${ }^{15)}$ respectively.

Amino acid analysis was performed with a Hitachi model 825 amino acid analyzer. Preparation of the hydrolysate for the analysis was carried out by Stein-Moore's method. ${ }^{16)}$

\section{RESULTS}

\section{Polysaccharide production}

We determined the optimal culture conditions for polysaccharide production by $\mathrm{H}-2$ on the scale of a $500 \mathrm{ml}$ shaking flask containing $50 \mathrm{ml}$ of medium (Table I). The concentrations of nitrogen sources, sodium nitrate and ammonium chloride, of this medium (VCRP20) were reduced to a half in comparison with those of the VCR medium. Based on these conditions, we carried out a 2-liter jar culture. As shown in Fig. 1, the maximum polysaccharide production was $1.8 \mathrm{~g}$, together with $3.6 \mathrm{~g}$ of dry cells, per liter of the culture

Table I. Optimal Culture Conditions for Polysaccharide Production

\begin{tabular}{ll}
$\mathrm{NaNO}_{3}$ & $1.0 \mathrm{~g} /$ liter \\
$\mathrm{NH}_{4} \mathrm{Cl}$ & 0.25 \\
$\mathrm{KH}_{2} \mathrm{PO}_{4}$ & 0.7 \\
$\mathrm{~K}_{2} \mathrm{HPO}_{4}$ & 2.6 \\
$\mathrm{MgSO}_{4} \cdot 7 \mathrm{H}_{2} \mathrm{O}$ & 0.4 \\
$\mathrm{CaCl}_{2} \cdot 2 \mathrm{H}_{2} \mathrm{O}$ & 0.02 \\
$\mathrm{FeCl}_{3}$ & $8.0 \mathrm{mg} /$ liter \\
$\mathrm{CuSO}_{4} \cdot 5 \mathrm{H}_{2} \mathrm{O}$ & 0.5 \\
Vitamin $\mathrm{B}_{12}$ & $1.0 \mu \mathrm{g} /$ liter \\
$\mathrm{pH} \mathrm{7.2}$ & Temperature $50^{\circ} \mathrm{C}$ \\
Mixed gas $\mathrm{CH}_{4}-\mathrm{O}_{2}-\mathrm{CO}_{2}-$ air $=7: 2: 1: 10$ \\
\hline
\end{tabular}

broth. The microorganism produced polysaccharides in proportion to the growth.

During the investigation of the optimal phosphate concentration in the medium for polysaccharide production by the microorganism, we observed that polysaccharide productivity of the microorganism was irreversibly decreased when the cultivation was car-

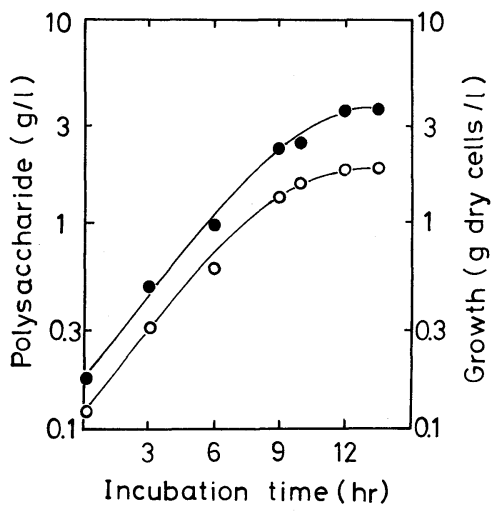

FIG. 1. Time Courses of Polysaccharide Production by $\mathrm{H}-2$ and the Growth.

The fermentation was carried out in a 2-liter glass jar fermentor containing 1 liter of VCRP20 medium as described in the text. The flow rates of methane and oxygen fed into the fermentor were $300 \mathrm{ml} / \mathrm{min}$ and $5 \mathrm{ml} / \mathrm{min}$, respectively, as measured with thermal-massflow meters. Symbols: 0 , growth; $\bigcirc$, total polysaccharide produced.

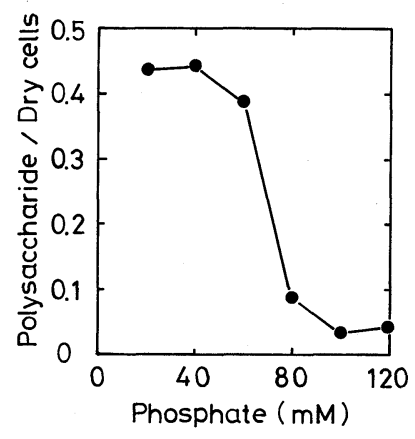

Fig. 2. Effect of Phosphate on Polysaccharide Productivity.

The protocol of investigation of the effect of phosphate on polysaccharide productivity of $\mathrm{H}-2$ was as follows: The microorganisms cultured for 20 hours in test media which contained different concentrations of phosphate, 20 to $120 \mathrm{~mm}$, were inoculated into VCRP20 medium. They were further cultured for 20 hours, and measurements of dry cell weight and polysaccharide in the medium were carried out as described in the text. 
Table II. Effect of Curing Agents on Polysaccharide Productivity

This test was carried out as follows: The microorganism grown in a $100-\mathrm{ml}$ shaking flask containing $10 \mathrm{ml}$ of VCRP20 medium with an agent for 24 to $72 \mathrm{hr}$ was transferred to a $500-\mathrm{ml}$ shaking flask containing $50 \mathrm{ml}$ of VCRP20 medium. After it had grown to OD 1.5, polysaccharide production was measured as described in Materials AND Methods.

\begin{tabular}{lccc}
\hline \multicolumn{1}{c}{ Agent } & $\begin{array}{c}\text { (A) Number of } \\
\text { isolated } \\
\text { colonies }\end{array}$ & $\begin{array}{c}\text { (B) Number of } \\
\text { polysaccharide- } \\
\text { productive colonies }\end{array}$ & $\begin{array}{c}\text { Ratio of } \\
\text { (B)/(A) }\end{array}$ \\
\hline Acridine orange $\left(2.0 \mu \mathrm{g} / \mathrm{ml}^{*}\right)$ & 18 & 16 & 0.89 \\
Mitomycin C $\left(0.5 \mu \mathrm{g} / \mathrm{ml}^{*}\right)$ & 15 & 2 & 0.13 \\
Ethidium bromide $\left(0.5 \mu \mathrm{g} / \mathrm{ml}^{*}\right)$ & 20 & 16 & 0.80 \\
Sodium dodecyl sulfate $\left(10 \mu \mathrm{g} / \mathrm{ml}^{*}\right)$ & 21 & 3 & 0.14 \\
Phosphate $(80 \mathrm{~mm})$ & 20 & 1 & 0.05 \\
$(40 \mathrm{mM})$ & 20 & 18 & 0.90 \\
$(20 \mathrm{~mm})$ & 42 & 42 & 1.00 \\
\hline
\end{tabular}

* Critical concentrations of curing agents for growth of the microorganism.

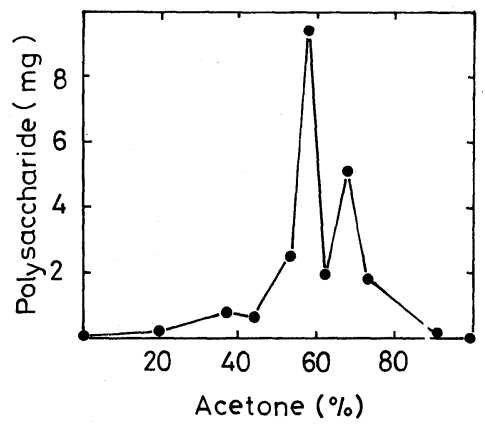

FIG. 3. Fractionation of Polysaccharide.

Thirty mg of crude acidic polysaccharide was fractionated by stepwise precipitation with acetone. The recovery was $79 \%$.

ried out in a medium containing more than $80 \mathrm{~mm}$ phosphate (Fig. 2). The microorganism which had lost the ability of production was cultured in VCRP20 medium for 28 days with 10 successive transfers. But the productivity was not recovered. No irreversible decrease of productivity occurred on changing any other components of the culture medium. In addition, we found that the productivity was lost on treatment of the cells with acridine orange, ethidium bromide, mitomycin $\mathrm{C}$ or sodium dodecyl sulfate. In particular, the productivity was easily lost with mitomycin $\mathrm{C}$ and sodium dodecyl sulfate (Table II).

\section{Purification of polysaccharide}

Crude acidic polysaccharide precipitated

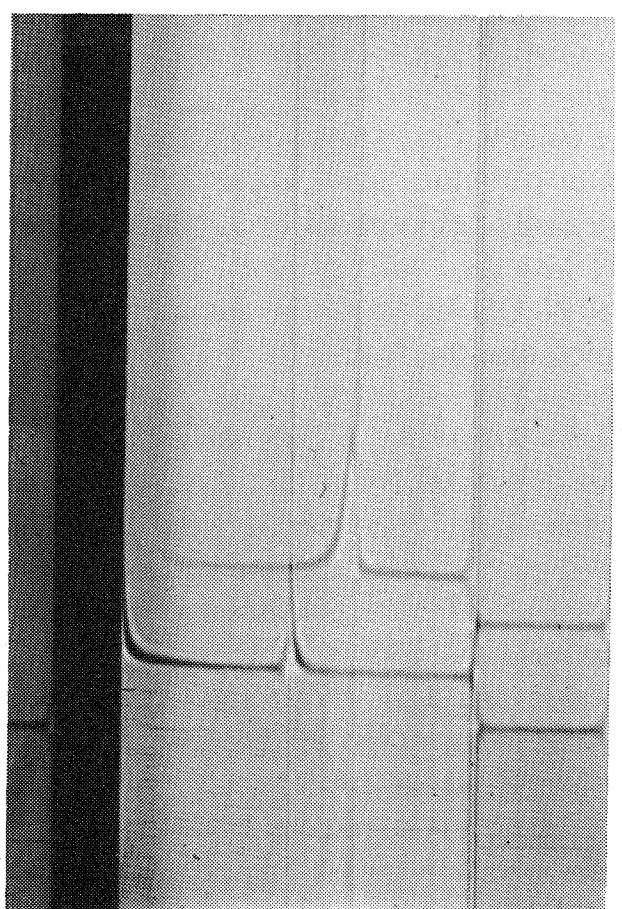

Fig. 4. Profiles of Polymer I and Polymer II on Centrifugal Analysis.

Polymer I is top and Polymer II is bottom. This picture was taken on centrifugation at $1890 \times g$ for $80 \mathrm{~min}\left(25^{\circ} \mathrm{C}\right)$. The solvent was $10 \mathrm{~mm} \mathrm{Na-phosphate} \mathrm{buffer} \mathrm{(pH} \mathrm{7.2).}$

with CTAB was effectively fractionated by stepwise preciptation with acetone, so that two kinds of acidic polysaccharides were obtained. As shown in Fig. 3, one was precipitated at $50 \sim 55 \%$ acetone (Polymer I) and the other at 
$60 \sim 65 \%$ acetone (Polymer II). Each polysaccharide gave a single peak on analytical centrifugation (Fig. 4). The ratio of Polymer I and Polymer II produced in the crude acidic polysaccharide fraction was about two to one throughout the cultivation period.

Capsular polysaccharides were isolated from the microorganism by treatment with $0.05 \mathrm{~N} \mathrm{NaOH}$ at $4^{\circ} \mathrm{C}$ for $30 \mathrm{~min}$, but they were not recovered in the acidic fraction.

Physicochemical properties of the polysaccharide

Some physicochemical properties of Polymer I and Polymer II are shown in Table III. The molecular weight of Polymer II was about three times greater than that of Polymer I, though Polymer I was more viscous than Polymer II. Additionally, both polysaccharide were colloidal in more than $5 \%$ trichloroacetic acid or perchloric acid. These polysaccharides were easily decomposed by alkali and irreversibly lost their viscosities on treatment with $0.1 \mathrm{~N} \mathrm{NaOH}$ at $98^{\circ} \mathrm{C}$ for $2 \mathrm{~min}$ or at room temperature for $24 \mathrm{hr}$.

\section{Components of the polysaccharide}

As shown in Table IV, sugar contents of Polymer I and Polymer II were $36.5 \%$ and $56.1 \%$, respectively, and the sugars consisted of glucose, mannose, galactosamine and glucuronic acid in approximate molar ratios of $1: 1: 5: 5$ and $1: 4: 9: 6$, respectively. The results of elementary analyses revealed that Polymer I and Polymer II contained $6.2 \%$ and $5.0 \%$ of nitrogen, respectively. In the hydrolysates of these polysaccharides treated with

Table III. Physicochemical Properties of Polymer I AND Polymer II

\begin{tabular}{lrc}
\hline & Polymer I & Polymer II \\
\hline $\begin{array}{c}\text { Sedimentation coefficient } \\
(\mathrm{S})\end{array}$ & 3.9 & 5.7 \\
$\begin{array}{c}\text { Limiting viscosity number } \\
(\mathrm{dl} / \mathrm{g})\end{array}$ & 15.5 & 9.6 \\
$\begin{array}{c}\text { Specific rotatory power } \\
\text { (degree) } \\
\text { Molecular weight }\end{array}$ & +36 & +38 \\
\hline
\end{tabular}

$0.05 \mathrm{~N} \mathrm{HCl}$ at $80^{\circ} \mathrm{C}$ for $60 \mathrm{~min}$, no sialic acid was detected by Aminoff's method. ${ }^{17)}$ Only galactosamine was detected in both polysaccharides by GLC and TLC as a nitrogen containing sugar. So, nitrogen contents of Polymer I and Polymer II due to their sugar components were only $1.3 \%$ and $1.8 \%$, respectively.

Then protein contents of these polysaccharides were measured by Lowry's method ${ }^{18)}$ with bovine serum albumin as standard. Polymer I and Polymer II contained $28.4 \%$ and $5.0 \%$ of protein, respectively. Amino acid compositions of hydrolysates of both polysac-

TABle IV. Sugar Components OF POLYMER I AND POLYMer II

\begin{tabular}{lcc}
\hline \multicolumn{1}{c}{ Sugar } & $\begin{array}{c}\text { Polymer I } \\
(\%)\end{array}$ & $\begin{array}{c}\text { Polymer II } \\
(\%)\end{array}$ \\
\hline Glucose & 3.2 & 2.1 \\
Mannose & 2.9 & 10.5 \\
Galactosamine & 16.8 & 23.3 \\
Glucuronic acid & 13.6 & 19.6 \\
\hline Total & 36.5 & 56.1 \\
\hline
\end{tabular}

TABle V. Amino Acid Compositions of Polymer I AND Polymer II

\begin{tabular}{lcc}
\hline \multicolumn{1}{c}{ Amino acid } & $\begin{array}{c}\text { Polymer I } \\
(\%)\end{array}$ & $\begin{array}{c}\text { Polymer II } \\
(\%)\end{array}$ \\
\hline Aspartic acid & 3.33 & 0.63 \\
Threonine & 2.91 & 0.19 \\
Serine & 1.35 & 0.29 \\
Glutamic acid & 3.42 & 2.97 \\
Glycine & 3.86 & 6.63 \\
Alanine & 2.10 & 0.35 \\
Cysteine & 0.40 & 0.56 \\
Valine & 5.10 & 9.80 \\
Methionine & $\mathrm{n} . \mathrm{d}$. & 0.22 \\
Isoleucine & 1.40 & 0.26 \\
Leucine & 2.66 & 0.33 \\
Tyrosine & 3.80 & 5.95 \\
Phenylalanine & 1.62 & 0.51 \\
Lysine & 1.08 & $\mathrm{n} . \mathrm{d}$. \\
Histidine & 1.31 & $\mathrm{n} . \mathrm{d}$. \\
Arginine & 1.74 & 0.24 \\
Tryptophan & 0.46 & 0.83 \\
Proline & 1.19 & $\mathrm{n} . \mathrm{d}$. \\
\hline Total & 37.7 & 29.8 \\
\hline & & \\
\hline & & \\
\hline
\end{tabular}

n.d., not detected. 
charides are given in Table V. Methionine was not detected in Polymer I. In Polymer II, lysine, histidine and proline were not detected, while four major components, valine, glycine, tyrosine and glutamic acid, occupied $85 \%$ of the total amino acids. So, the results of amino acid analyses were quite different from those obtained with Lowry's method. As a result of amino acid analyses, Polymer I and Polymer II were found to contain $37.7 \%$ and $29.8 \%$ of amino acids, respectively.

\section{DISCUSSION}

Accumulation and excretion of polysaccharides has been reported in some methanotrophs. ${ }^{19)}$ Methylococcus NCIB $11083^{20)}$ grown on methane under nitrogen limitation, accumulates polyglucoses in the cell. Methaneoxidizing bacterium $\mathrm{H}-2$ can produce two kinds of extracellular polysaccharides, Polymer I and Polymer II, without nitrogen limitation. But they cannot function as a reserve carbon and energy source because the microorganism is not able to remetabolize them. We are investigating their roles in the microorganism.

A mixed methane-oxidizing culture is reported to produce heteropolysaccharides containing glucose, galactose, mannose, fucose and rhamnose. ${ }^{8)}$ Sugar components of Polymer I and Polymer II produced by $\mathrm{H}-2$ are quite different from those of the latter heteropolysaccharides. Polymer I and Polymer II consist of glucose, mannose, galactosamine and glucuronic acid in approximate proportions of $1: 1: 5: 5$ and $1: 4: 9: 6$, respectively, and moreover consist of about $38 \%$ and $30 \%$ of amino acids, respectively. Protein contents of the polysaccharides estimated by Lowry's method are less than those by amino acid analyses. One reason for this is that the polysaccharides have less chromogenic groups ${ }^{21}$ ) than bovine serum albumin used as a standard for Lowry's method. Both polysaccharides seem to be glycoproteins which involve $O$ glycosidic linkage to hydroxyamino acid because they are alkali-labile and contain thre- onine and serine. ${ }^{22)}$

On growth in media containing more than $80 \mathrm{~mm}$ phosphate, $\mathrm{H}-2$ irreversibly loses the ability of polysaccharide productivity. It can be thought that the polysaccharide production depends on a plasmid which is eliminated by phosphate in medium, because the productivity has also been irreversibly lost with agents (mitomycin C, sodium dodecyl sulfate, ethidium bromide and acridine orange) which can remove plasmids from bacteria, ${ }^{23}$ though we have not yet been able to detect the plasmid in $\mathrm{H}-2$ by Hansen-Olsen's method. ${ }^{24)}$

Polymer I and Polymer II are the first extracellular substances produced on pure cultivation of a methane-oxidizing bacterium from methane as a single carbon and energy source.

Acknowledgment. This work was supported in part by a grant from the Foundation for the Promotion of Research on Medicinal Research.

\section{REFERENCES}

1) J. R. Quayle, Ann. Rev. Microbiol., 15, 119 (1961).

2) D. W. Ribbons, J. E. Harrison and A. M. Wadzinski, Ann. Rev. Microbiol., 24, 135 (1970).

3) R. Whittenbury, K. C. Philips and J. F. Wilkinson, J. Gen. Microbiol., 61, 205 (1970).

4) G. J. Shen, T. Kodama and Y. Minoda, Agric. Biol. Chem., 26, 191 (1982).

5) C. T. Hou, A. I. Laskin and R. N. Patel, Appl. Environ. Microbiol., 37, 800 (1979).

6) Y. Tani, T. Kanagawa, A. Hanpongkittikun, K. Ogata and H. Yamada, Agric. Biol. Chem., 42, 2275 (1978).

7) N. L. Söhngen, Zentr. Bakt. Parasitenk, 15, 513 (1906).

8) M. N. Huq, B. J. Ralph and P. A. Richard, Aust. J. Biol. Sci., 31, 311 (1978).

9) M. Dubois, K. A. Gilles, J. K. Milton, P. A. Rebers and F. Smith, Anal. Chem., 28, 350 (1956).

10) D. A. Yphantis, Biochem., 3, 297 (1964).

11) A. E. Gal, Anal. Biochem., 24, 452 (1968).

12) J. S. Sawardeken and J. H. Sloneken, Anal. Chem., 37, 945 (1965).

13) J. Karkkainen, A. Lehtonet and T. Nikkari, $J$. Chromatogr., 20, 457 (1965).

14) L. A. Elson and W. T. L. Morgan, Biochem. J., 27, 1824 (1933).

15) T. Bitter and M. M. Muir, Anal. Biochem., 4, 330 (1962). 
16) S. Moore and W. H. Stein, Methods Enzymol., 6, 819 (1963).

17) D. Aminoff, Biochem. J., 81, 384 (1961).

18) O. H. Lowry, N. J. Rosebrough, A. L. Farr and R. J. Randall, J. Biol. Chem., 193, 265 (1951).

19) I. J. Higgins, D. J. Best, R. C. Hammond and D. Scott, Microbiol. Rev., 45, 556 (1981).

20) J. D. Linton and R. E. Cripps, Arch. Microbiol., 117, 41 (1978)
21) S.-C. Chou and A. Goldstein, Biochem. J., 75, 109 (1960).

22) F. Downs and W. Pigman, "Methods in Carbohydrate Chemistry," Vol. VII, ed. by R. L. Whinstler and J. N. BeMiller, Academic Press Inc., New York, N. Y., 1976, p. 200.

23) R. C. Crowes, Bacteriol. Rev., 36, 361 (1972).

24) J. B. Hansen and R. M. Olsen, J. Bacteriol., 135, 227 (1978). 